ISSN 1991- 8690

website: http:// jsci.utq.edu.iq

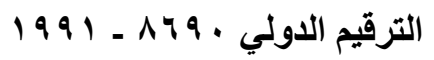

Email: utjsci@utq.edu.iq

\title{
Bacterial Infection and Hematological Parameters of aborted women in Thi-Qar province, Iraq
}
Qasim Hassan Wdaa ${ }^{(1)}$
Talib Falih Hassan ${ }^{(2)}$
Aseel Zghaer Sadoon

(1) College of pharmacy/university of Thi-qar

${ }^{(2)}$ Community Health Dep- Technical Institute/Al-Nasseria

\begin{abstract}
$\underline{\text { Abstract }}$
The Current study was performed among 40 aborted women whom referred Bint-AL Huda teaching hospital in Thi-Qar province, Iraq. During the period from August 2012 to April 2013. Vaginal swabs were collected, cultured and their susceptibility to various antibiotics was determined, A significant growth was obtained in (23) samples, Staphylococcus aureus, Escherichia coli was the most prevalent isolates. Blood sample were collected to perform complete blood count. Hematologic tests through complete blood count showed that the values of White blood cell count, Neutrophil, Lymphocyte, Monocyte and Eosinophil count was a significant higher in abortive women compare to the control group. But the study revealed significant decrease in hemoglobin level and red blood cell count of aborted women compared to control group.
\end{abstract}

$$
\begin{aligned}
& \text { الإصابات البكتيرية وتقييم المعايير الدموية لاى النساء المجهضات }
\end{aligned}
$$

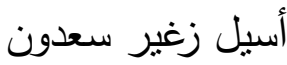

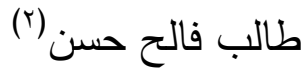

$$
\begin{aligned}
& \text { قاسم حسن وداعة(') } \\
& \text { (') (') كلية الصيدلة - جامعة ذي قار } \\
& \text { (') (بسم صحة المجتمع - المعهد التقني في الناصرية }
\end{aligned}
$$

اجريت الدراسة الحالية على •؛ من النساء المجهضات المراجعات لمستتفى بنت الهدى التعليمي في محافضة ذي قار / العراق تم

جمع المسحات المهبلية وزراعتها واختبرت حساسية العزلات للمضادات الحيوية .حيث كانت بكتيريا كscherichia coli

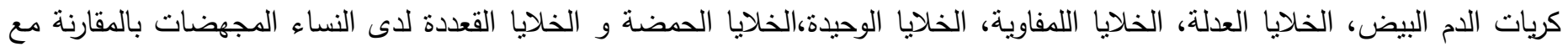

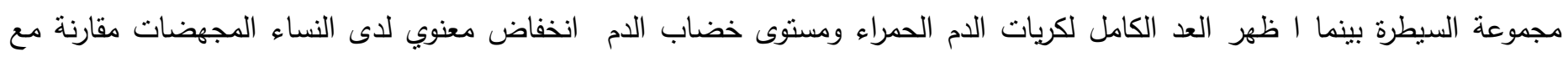
مجموعة السيطرة. 


\section{Introduction}

Spontaneous abortion is usually defined as an involuntary loss of an intrauterine pregnancy before fetal viability (George, 2006). According to the criteria of WHO spontaneous abortion defined as the expulsion of an embryo or extraction of the fetus weighting $500 \mathrm{~g}$ or less, this fetal weight will normally corresponding to gestational age of 20-22 weeks (Goddijn and Leschot, 2000). When abortion related with infection and complicated by fever, endometritis and parameritis called septic abortion, which remains one of the most serious threats to the health of women throughout the world (Prine and Macnaughton, 2011). The bacteria associated with septic abortion are usually polymicrobial, derived from the normal flora of the vagina and endocervix, with the important addition of sexually transmitted pathogens (Kaponis et al.,2012). There are number of different routes by which an infection may reach the intra-amniotic cavity transplacental spread of infection can occur in women with bacteremia, an infection of the abdominal cavity could spread via the fallopian tubes, but the most common routs is an ascending infection from bacteria colonize the vagina and or cervix (Seliga-siwecka and Kornacka 2011). Indirect evidence indicated that the most common pathway on intrauterine infection is the ascending route than other route (Anjum, 2011). Pelvic infections in pregnant women have their microbiologic origin in one of three sources: the endogenous vaginal microflora, the intestinal microflora, and sexual transmission, the infection occurs via migration of the organisms from the vagina through the endocervix into the uterus, Some organisms may traverse the columnar epithelium, as is the case with infection caused by Neisseria gonorrhoeae and Chlamydia trachomatis (Kaponis et al., 2012). Hematologic tests through blood screening help assess medical concerns and serve as baseline information for future monitoring of health. Complete blood count is one of the most commonly employed blood tests designed to evaluate the red and white blood cells (Zandeki et al., 2007).

\section{Material and methods}

Sample was collected from females with history of abortion who admitted to Bint-AL Huda teaching hospital and from women with history of normal birth without abortion as control group in Thi-Qar province, Iraq. During the period from August 2012 to April 2013.

Vaginal swab were collected from (40) aborted women, each vaginal swab inoculated on Blood agar plates MacConkey's agar, Chocolate agar and Manital salt agar plates, all plates incubated aerobically at $37^{\circ} \mathrm{C}$ for $24-48$ hours. The isolation and identification of and bacteria in vaginal swabs were performed through colony morphology of bacterial isolates, microscopic gram stain investigation, and biochemical tests (Forbes et al., 2007), isolates identification was also confirmed using API E-20 test system (Biomerieux, France).

Isolated organisms were subjected to sensitivity test by disc diffusion method using National Committee for Clinical Laboratory Standards criteria (NCCLS, 2007) to interpret diameter of inhibition zone.

Five $\mathrm{ml}$ of Blood sample was collected from aborted women $(2 \mathrm{ml}$ drown in EDTA tube for $\mathrm{CBC}$ test, $3 \mathrm{ml}$ for serum collection), the hematological Parameters (RBC, Hb, Hct,WBC, differential white blood cells and PLT) measured by using Cell-DYN Ruby® System operator's manual (is a multi-parameter automated hematology analyzer designed for in vitro diagnosis) according to the flow cytometric techniques (Cell-DYN 08H56-02, USA).

\section{$\underline{\text { Results }}$}

\section{Bacteriological Infection.}

Of all the 40 cultured samples, a significant growth was obtained in 23 samples, Out of 27 isolates Staphylococcus aureus and Escherichia coli was the most prevalent organism with the percentage (44.44\%), (40.74\%) respectively, followed by Klebsiella pneumoniae $(11.11 \%)$ and with the lower percentage(3.70\%), (fig. 1). 


\section{Percentage of bacteria}
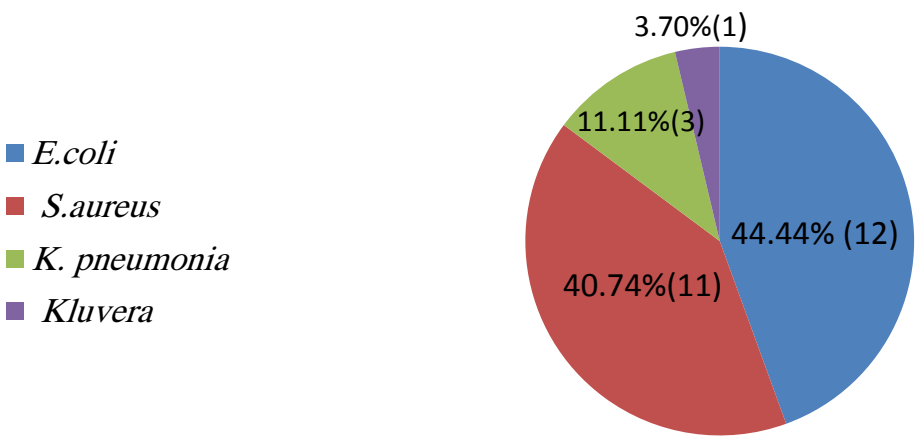

Figure (1) Frequency of bacterial isolates from abortive women.

As shown in table (1) Staphylococcus aureus was high sensitive to Norfloxacin $(58 \%)$, while all was resistant to (Ceftazidime, Lincomycin, Cloxacillin) The most effective chemotherapeutic agents observed against Escherichia coli in this study were Norfloxacin, while all was resistant to
(Ampicillin, Lincomycin, Cloxacillin), all isolate of Klebsiella pneumonia sensitive to Norfloxacin also all isolate resistant to (Ampicillin, Cefotaxime, Lincomycin, Nitrofuration, Naldixic acid, Cloxacillin ) and the only one isolate of Kluyvera Spp were sensitive only to Norfloxacin.

Table(1) Antibiotics susceptibility of bacterial isolates from aborted women.

\begin{tabular}{|l|l||l|l||l||}
\hline \hline Antibiotics & $\begin{array}{l}\text { Staphylococcus } \\
\text { aurus } \\
\mathrm{N}(\%)\end{array}$ & $\begin{array}{l}\text { Escherichia coli } \\
\mathrm{N}(\%)\end{array}$ & $\begin{array}{l}\text { Klebsiella } \\
\text { pneumonia } \\
\mathrm{N}(\%)\end{array}$ & $\begin{array}{l}\text { Kluyvera Spp } \\
\text { N }(\%)\end{array}$ \\
\hline \hline Ampicillin & $4(33.33 \%)$ & 0 & 0 & 0 \\
\hline \hline Piperacillin & $5(41.66 \%)$ & $2(18.18 \%)$ & $1(33.33 \%)$ & 0 \\
\hline \hline Cefotaxime & $3(25 \%)$ & $2(18.18 \%)$ & 0 & 0 \\
\hline \hline Ceftazidime & 0 & $1(9.09 \%)$ & $1(33.33 \%)$ & 0 \\
\hline \hline Norfloxacin & $7(58.33 \%)$ & $9(81.18 \%)$ & $3(100 \%)$ & $1(100 \%)$ \\
\hline \hline Amikacin & $2(16.66 \%)$ & $4(36.36 \%)$ & $1(33.33 \%)$ & 0 \\
\hline \hline Lincomycin & 0 & 0 & 0 & 0 \\
\hline \hline Nitrofuration & $2(16.66 \%)$ & $2(18.18 \%)$ & & 0 \\
\hline \hline Naldixic acid & $1(8.3 \%)$ & $5(45.45 \%)$ & 0 & 0 \\
\hline \hline Cloxacillin & \multicolumn{1}{|c|}{0} & 0 & 0 & 0 \\
\hline
\end{tabular}

\section{Hematological Parameters}

The differences between the mean of RBCs, HB, HCT, PLT and RBCs that occurred in study group, compared with the Control group shown in table (2).The RBCs count showed a significant decrease $(\mathrm{P} \leq 0.05)$ in study group $(4.74 \pm 0.41)$ compared with the Control group (4.92 \pm 0.35).The $\mathrm{Hb}$ concentration also showed a significant decrease $(\mathrm{P} \leq 0.05)$ in study group $(12.20 \pm 1.60)$ compared with the control group (12.86 \pm 0.79$)$. 
The HCT level showed a statistically nonsignificant decrease $(\mathrm{P}>0.05)$ in study group $(38.84 \pm 3.91)$ when compared to that of the control group (39.19 \pm 1.87$)$. The PLT level, showed a non-significant decrease $(\mathrm{P}>0.05)$ in study group (259.35 \pm 56.22$)$ compared with the control group (260.92 \pm 57.71).

Table (2) Differences between mean of RBCs, HB, Hct, PLT and RBCs in aborted women compare with the control group.

\begin{tabular}{l||c||c||c|}
\hline \multirow{2}{*}{ variables } & Control group & Study group & \multirow{2}{*}{$\operatorname{LSD}_{(0.05)}$} \\
\cline { 2 - 3 } & Mean \pm SD & Mean \pm SD & \\
\hline \hline RBCs10e $/ \mathrm{ul}$ & $4.92 \pm 0.35^{\mathrm{a}}$ & $4.74 \pm 0.41^{\mathrm{b}}$ & 0.14 \\
\hline \hline $\mathrm{Hb}$ g/dl & $12.86 \pm 0.79^{\mathrm{a}}$ & $12.20 \pm 1.60^{\mathrm{b}}$ & 0.5 \\
\hline \hline Hct \% & $39.19 \pm 1.87^{\mathrm{a}}$ & $38.84 \pm 3.91^{\mathrm{a}}$ & 1.36 \\
\hline PLT10e3/ul & $260.92 \pm 57.71^{\mathrm{a}}$ & $259.35 \pm 56.22^{\mathrm{a}}$ & 25.23 \\
\hline
\end{tabular}

The differences between total leucocytes and differential counts of leucocytes in study group compared with the control group presented in table (3). The total WBCs count showed significant increase $(\mathrm{P} \leq 0.05)$ in study group $(7.45 \pm 2.17)$ compared with the counts in the control group $(6.09 \pm 1.49)$. Neutrophils percentage increased significantly $(\mathrm{P} \leq 0.05)$ in study group $(56.86 \pm$ 10.03) compared to that of the Control count (52.97 \pm 7.44$)$. Lymphocytes percentage increased significantly $(\mathrm{P} \leq 0.05)$ in study group $(40.38 \pm$ 7.72) (32.13 \pm 8.39) compared with the control group (32.13 \pm 8.39) the Monocytes percentage showed a significant increased in study group (7.20 1.99$)$ compared with the Control percentage (5.97 \pm 1.39$)(\mathrm{P} \leq 0.05)$. The Eosinophils percentage showed a non-significant decrease $(\mathrm{P}>0.05)$ in study grope $(2.80 \pm 2.29)$ when compared with the control percentage $(3.13 \pm 2.08)$. Also the Basophils percentage showed a statistically insignificant decrease in study grope $(0.88 \pm 0.52)$ when compared to that of the Control percentage $(1.04 \pm 0.56)(\mathrm{P}>0.05)$.

Table (3): Differences between total leucocytes and differential counts of aborted women compare with Control group.

\begin{tabular}{|c|c|c||c||}
\hline \multirow{2}{*}{ variables } & Control group & Study group & \multirow{2}{*}{ LSD $_{(0.05)}$} \\
\cline { 2 - 3 } & Mean \pm SD & Mean \pm SD & \\
\hline \hline WBC10e $^{6} / \mathrm{ul}$ & $6.09 \pm 1.49^{\mathrm{b}}$ & $7.45 \pm 2.17^{\mathrm{a}}$ & 1.29 \\
\hline \hline NEU\% & $52.97 \pm 7.44^{\mathrm{b}}$ & $56.86 \pm 10.03^{\mathrm{a}}$ & 3.2 \\
\hline \hline LYM\% & $32.13 \pm 8.39^{\mathrm{b}}$ & $40.38 \pm 7.72^{\mathrm{a}}$ & 3.56 \\
\hline \hline MONO\% & $5.97 \pm 1.39^{\mathrm{b}}$ & $7.20 \pm 1.99^{\mathrm{a}}$ & 0.77 \\
\hline \hline EOS\% & $3.13 \pm 2.08^{\mathrm{a}}$ & $2.80 \pm 2.29^{\mathrm{a}}$ & 0.97 \\
\hline \hline BASO\% & $1.04 \pm 0.56^{\mathrm{a}}$ & $0.88 \pm 0.52^{\mathrm{a}}$ & 0.24 \\
\hline
\end{tabular}

WBCs: White blood cells, NEU: Neutrophils, LYM: Lymphocytes, MONO: Monocytes, EOS: Eosinophils, BASO: Basophils. 


\section{Discussion}

In this study most bacterial isolated was Escherichia coli and Staphylococcus aureus(Table 1) this result was agreement with result of Razzak et al., (2011) and Mumtaz et al. (2008). Ascending uterin infection from the lower genital tract due to bacteria has been implicated as an important causative factor for many pregnancy complication one of them spontaneous abortion (Tripathi et al., 2003).

Kaponis et al. (2012) showed that the one of the most frequent causative pathogens are Aerobic Bacteria (Escherichia coli, Staphylococcus aureus, group B $\beta$-hemolitic Streptoccocus, Enteroccocus, other Streptoccocus species, Hemophilus Influenzae, Pseudomonas species, Klebsiella, Enterobacter species, Proteus species.

Also Deb et al., (2004) found that the Genital tract infections caused by gram-negative bacteria induce abortion and are one of the most common complications of human pregnancy.

Buchmayer, (2008) refer to that the some bacterial infection from the vagina after ascend through the cervix into the choriodecidual space may then cross the intact membrane of the amniotic fluid and possibly also infect the foetus.

After ascending and spread of bacteria the mechanism by which bacterial infection causes abortion are believed to be related to inflammation (Romero,et al.,2007).

Bacterial infection release toxins which activate cytokine production, this inflammatory response may then culminate in spontaneous abortion (Bunchmayer, 2008).cytokine production stimulates neutrophil infiltration and prostaglandin synthesis leading to increase levels of metalloproteases which in turn causes cervical ripening, weakening and rupture of chorioamniotic membrane, Prostaglandins also stimulate uterine contractions (Seliga-siwecka and Kornacka 2011). Also release of cytokines may alter the normal physiology of the reproductive organs of the mother, and may shift the delicate estrogen/progesterone ratio required for the maintenance of successful pregnancy (Deb et al.,2004).Several of these cytokines have been implicated in the delicate immune system balances that exist within the feto-maternal interface, any disturbance of this delicate immune balance within the maternal-fetal interface may result in abortion (Kauma,2000) Also these cytokines can act in gestational tissues to damage placental blood supply and function and cause fetal injury leading ultimately to placental and fetal demise( Robertson et al.,2007).

But the study revealed significant decreases in RBCs count and $\mathrm{HB}$ respectively of aborted women compared to control group $(\mathrm{P} \leq 0.05)$, while the values of PCV and PLT revealed insignificant slightly decreases in aborted women compare to the control group ( $\mathrm{P}>0.05)$.

Pregnancy causes significant changes in metabolism, fluid balance, organ function and blood circulation which are driven by hormones and the presence of the feto - placental unit, these dramatic changes influence a wide variety of hematological parameters, decreasing in $\mathrm{RBC}, \mathrm{Hb}$, PCV some of these change which due to increasing plasma volume (Elgari, 2013).

And these parameters return to the normal range after 8 week of birth (Firki et al. 2002), so these decreasing in RBC, HB, PCV, PLT of abortive women which reported in this study may due to the effect of aborted pregnancy, or May due to lost blood during abortion.

In this study group the values of WBC count ,NEU, LYM, MONO, was significant higher compare to the control group, EOS and BASO value of study group lower than that of control group but it is difference non-significant.

White blood cells are an important component of the host defense system, responsible for protection against bacteria, fungi, viruses, and invading parasites, it is level elevated during infection, Neutrophils was frequently increased in infection and in any acute inflammation also it is the primary $\mathrm{WBC}$ that primary respond to a bacterial infection, Lymphocyte increased due to acute viral and bacterial infection, less commonly, increased Lymphocyte may result of toxoplasmosis, increased Monocyte level associated with infection and inflammation processes, the main causes of 
increased Eosinophils is parasitic infection (Stock and Hoffman, 2000).

Total leukocyte count rising in early pregnancy which remained elevated through pregnancy (Osonuga et al., 2011).

Neutrophils contribute most to the overall higher WBC (Edlestam et al., 2001). Also elevated WBC back to normal value by 4 weeks post-partum (Firki et al. 2002).so the elevated in WBC level which still within normal values may due to the effect of aborted pregnancy.

This study agreement with study of Hama and Abdurahman (2013) in Sulaimani, Kareem (2012) and AL-Ghezy (2012) which showed that the RBC count, HB, PCV, PLT, WBC count ,NEU, LYM, MONO, EOS still within the normal range of normal adult women .

\section{References}

AL-Ghezy, S., (2012).Diagnostic study of Toxoplasma gondii and Cytomegalovirus in pregnantand aborted Women with some Epidemiological and Immuntyparametery in Thi-Qar province-Iraq. M.S.C. Thesis. College of Education for pure science. University of Thi-Qar.

Anjum, M. (2011). Study of bacterial vaginosis in pregnancy and its maternal and fetaloutcome. M.S.C. Thesis. Yenepoya medical college. University of health sciences.

Bunchmayer S. (2008).infection and infections related morbidity during pregnancy- short and long term effect. Thesis. Department of medical epidemiology and Biostatic Karolinskainstitutet, Stockholm, Swed. Pp 11.

Deb K., Chaturvedi M. and Jaiswal y. (2004). Aminimum dose of LPS required for implantation failure: assessment of its effect on the maternal reproductive organ and interlukin-1 $\alpha$ expression in the mouse. Reproduction, 128: 87-97.

Edlestam G, Lowbeer C, Kral G. (2001). New reference values for routine blood samples and human neutrophiliclipocalin during third trimester pregnancy.Scandinavian Journal of
Clinical Laboratory Investigation, 61: 583592.

Elgari,M. (2013). Evaluation of Hematological Parameters of Sudanese Pregnant Women attending at Omdurman Al Saudi Maternity Hospital Acad. J. Biolog. Sci, 5: 37 - 42.

Firki,F.; Chesterma C.; Peningto D. and Rus, B. (2002) Clinical Haematology in Medical Practice. 5th ed. London: Blackwell Publishing Ltd.

Forbes, BA, Daniel FS, Alice SW (2007). Baily and Scott's diagnostic microbiology. $12^{\text {th }}$, MOSBY. ELSEVIER.

George, L.; Granath, F.; Johansson, A; Olanoler, B. and Chattingius S. (2006) Risk of repeated miscarriage. Paediatr Perinat Epidemiology. 20: 26-119.

Goddijn, M and Leschot N. (2000).Genetic aspects of miscarriage. Baillieres Best Pract Res Clin Obstet Gynaecol, 4:855.

Hama S., and Abdurahman K., Human (2013)Cytomegalovirus IgG and IgM Seropositivity among Pregnant Women in Sulaimani City and Their Relations to the Abortion Rates. Current Research Journal of Biological Sciences ,5: 161-167.

Kaponis, A. Filindris Theodoros and Decavalas George.(2012). Septic Shock in Obstetrics and Gynecology, Severe Sepsis and Septic Shock - Understanding a Serious Killer, Dr Ricardo Fernandez (Ed.). , InTech. Pp. 312334.

Kareem S. (2012) First trimester spontaneous abortion: a clinicopathological view. Diyala Journal of Pure Sciences, 8: 159-174.

Kauma, S. (2000) Cytokines in implantation. Journal of Reproduction and Fertility Supplement, 55: 31-42.

Mumtaz S., Ahmad M., Aftab I., Akhtar N., ul H. (2008). Aerobic vaginal Pathogenes and their sensitivity pattern.) J Ayub Med. Coll. Abbottabad, 20:113-117.

National Committee for Clinical Laboratory Standards (NCCLS). (2007). Performance standards for Anti microbial susceptibility testing; seventeenth Informational 
Suppliment. standard M2-A9. M100-S16, 27.

Osonuga I.; Osonuga O.; Onadeko A.; Osonuga A. and Osonuga A. (2011). Hematological profile of pregnant women in southwest of Nigeria.Asian Pacific Journal of Tropical Disease . 232-234.

Prine Linda. and Macnaughton Honor. (2011) Office management of early pregnancy loss. American Family Physician, 84: 7684.

Razzak M., Al-CharrakhAlaa, AL-Greitty Bara. (2011)Relationship between lactobacilli and opportunistic bacterial pathogens associated with vaginitis. North American Journal Of Medical Science, 3:185-192.

Robertson S. , Care 2 Alison S., (2007) . and

Skinner Rebecca J. Interleukin 10

Regulates Inflammatory Cytokine Synthesis to Protect Against Lipopolysaccharide-Induced Abortion and Fetal Growth Restriction in Mice1. Biology Of Reproduction, 76:738-748.

Romero, R.; Espinoza, J.; Goncalves, L.; Kusanovic, J.; Friel, L and Hassan, S.(2007). The role of inflammation and infection in preterm birth. Semin Repord Med, 25:21-39.

Seliga-Siwecka J. and Kornacka M.(2011). Bacterial vaginosis, intrauterine infection, neonatal outcome- a review of current knowledge Archives of Perinatal Medicine, 17: 69-71.

Stock, W.and Hoffman R. (2000) White blood cells 1: non-malignant disorders. The Lancet, 355: 1351-1357.

Tripathi .R, Dimri S., Bhalla P. and Ramji S. (2003) Bacterial vaginosis and pregnancy outcomeInternational Journal of gynaecology and Obstertics, 83: 193-195.

Zandecki, M.; Genevieve, F.; Gerard J. and Godon A. (2007) Spurious counts and spurious results on haematology analysers: a review. Part II: white blood cells, red blood cells, hemoglobin, red cell indices and reticulocytes. International Journal Of Laboratory Hematology, 29: 21-41. 